\title{
Woman in The Vulnerability and Disaster Risk of Merapi Eruption in Indonesia
}

Hastuti Hastuti ( $\square$ hastuti@uny.ac.id)

Universitas Negeri Yogyakarta

\section{Edi Widodo}

Yogyakarta State University

\section{Sri Rum Giyarsih}

Gadjah Mada University

\section{Pramaditya Wicaksono}

Gadjah Mada University

\section{Research}

Keywords: Woman, Vulnerability, Merapi Eruption, Disaster risk.

Posted Date: March 23rd, 2020

DOl: https://doi.org/10.21203/rs.3.rs-17252/v1

License: (9) This work is licensed under a Creative Commons Attribution 4.0 International License. Read Full License 


\section{Abstract}

This study was aimed to depict the characteristics of women's vulnerability, as well as to study and analyze their efforts to reduce the disaster risk of Merapi eruption in the South Merapi Slope, Sleman Regency, Yogyakarta Special Territory. The data collection was conducted through interviews on the demographic characteristics of the women, with qualitative data consisting of the social and economic condition in the area under study, including the women's demographic characteristics, vulnerability, and risk. The qualitative data were used to complement the quantitative data obtained in the first data collection stage. Thus, the research data analysis was based on the quantitative and qualitative data. The results showed that women were vulnerable in terms of their financial security, particularly due to their lack of bank saving, protection in the place of business, land, and residence. Their social vulnerability was shown by how most of the women and elderly people in the households of the area under study required protection when disaster occurred. The vulnerability in organizations was due to the lack of organizations to care for the women. Most women also experienced environmental vulnerability.

\section{Introduction}

As an active fault, Indonesia's natural geographical landscape can be categorized as a disaster-prone area. Natural disasters are inevitable and usually a result of either tectonic shift (tectonic earthquakes, volcanic eruption), or climate change (storm, typhoon, draught); both may lead to serious damage in humans' lives. Common natural disasters in Indonesia, such as flood, landslide, draught, and (water, air, land) pollutions, are typically initiated by human behaviors in mismanaging natural resources. Indonesia is where the world's active faults meet, making the tectonic plate shift constantly occur, resulting in earthquakes and tsunami (Tuswadi \& Takehero Hayashi, 2014). As a country with the most active volcanoes in the world, the threats of volcanic eruption are facing the country from Sumatera, Java, Nusa Tenggara, to Celebes (Sulawesi).

Indonesia is the area where the active tectonic plates of the world meet and cause a shift resulting in earthquakes, tsunami, and active volcanic activities. The condition is made worse by the careless treatment of the people and their unawareness of the importance of environmental support system, thus leading to natural disasters such as flood, landslide, draught, and pollution in the water, air, and land.

There are a series of natural disasters waiting to occur and affect the lives of the Indonesian people. The threat of natural disasters in Indonesia occurs due to the meeting of the earth's active fault in addition to human's destructive behavior to the environment. Disaster risk reduction (DRR) focuses on long-term risk reduction by addressing the causal factors of risk in terms of the occurrence of natural hazards, the exposure to natural hazards and the vulnerability of communities (UNDP, 2007).

Mount Merapi (elevation: 2,968 m per 2006) is an active volcano in central Java Island and one of the most active volcanoes in Indonesia. The mountain is dangerous due to its regular eruption (active peak) every two to five years, while the volcano is surrounded by populous housing complex to the $1700 \mathrm{~m}$ height and $4 \mathrm{~km}$ away from the summit. Since 1548, the mountain has erupted 68 times (Sea Eun Cho, 
Sehyung Won, \& Saehoon Kim, 2016). This periodical threat demands the awareness of the community, particularly those residing in the Merapi Slope.

In the events of the frequent natural disaster, women are marginalized as the disaster management are more male-oriented. Natural disasters cause both material damage and loss of lives, and do not see gender difference. Nevertheless, women are the group of people that are less cared for in the event of natural disasters such as flood, draught, volcanic eruption, earthquake, tsunami, landslide, or endemic disease, and which make them incredibly vulnerable.

The low quality of life due to poverty has caused the poor, especially women, to be more vulnerable to diseases during the event of disasters. Women and children are the most vulnerable when a disaster strike, and even more afterward. Women also have worse experiences due to the inequality and unjust treatments in the post-disaster management. Structurally, disasters make women more prone to poverty and marginalization in the disaster management, particularly when the area affected by the disaster is a poor area. The social construction of women in the society is to be the subordinated group in comparison to men; as a result, they have lack of access to information, including when a disaster occurs to the mitigation stage of the disaster.

Women's limitation to access affects the mitigation and recovery process due to disaster, making them suffer more when disasters strike. During the occurrence of a disaster, women still have to do their domestic duties, such as caring for the children, the elderly, and other family members with physical disabilities. Unlike their male counterparts who are free of domestic duties, women do not have the freedom of mobility both to look for a place to live or to find a job.

Natural disasters should be taken as an opportunity for women to change their gender status in the society. Their very presence during the disaster is highly crucial as they are more flexible in moving the masses during emergency. They are able to form groups and social networks by working together when there is a demand and disaster mitigation. In the event of disaster, women can manage the available resources by creating productive activities to meet their daily needs. However, exactly when disaster occurs, they are the ones that must bear the higher domestic burden to take care of family members with physical limitation due to the disaster. They will be continually marginalized unless they seek recognition of their actions and existence as the essential figures during the occurrence of a disaster.

Women need to be aware that they should be in a constant effort to reduce the negative impacts of a disaster. The efforts include preparing for disaster as women understand more about the threats of disaster in relation to their own lives. According to the 2014 and 2015 National Census, National Statistics released the number of Indonesian populations as many as 254.9 million people. The data show that the male population is 128.1 million, and that the female population is 126.8 million people (BPS,2015). Women are the members of society that is most vulnerable when disaster occurs. It needs to be taken into account that the population of women is almost half of the total Indonesian population and therefore, they deserve proper attention and care. Women are relatively vulnerable in the occurrence of 
disaster; for this reason, it is important that women play a more significant role in dealing with disaster as it is one of the most important factors in reducing loss resulted from the disaster.

A thorough understanding of disaster risks and safety is the top priority in anticipating a disaster. The integration of necessary information regarding disaster risk in the daily lives is a strategic step in reducing unwanted disaster risk. Women need to be familiar with their surrounding in order to understand natural changes. An understanding of the natural changes is an important prerequisite in disaster risk rescue. In order to attain this objective, it is expected that women are to be more involved and given a bigger role in disaster management, so that they are able to defend themselves and their families from disaster risk.

Some of the areas in Indonesia are faced with problems that can trigger sudden poverty, i.e., the occurrence of natural disasters and threats such as draught, flood, volcanic eruption, earthquake, landslide, and forest fire. It is indeed ironic that women must suffer more in the occurrence of disaster and disaster management due to the difference in gender status which causes them to have lower bargaining power. Disasters make women more prone to poverty, as they often lose the breadwinner of the family.

The periodical Merapi eruption often results in material loss, and even take lives, particularly in the slope and river basin area with a direct path to Merapi. There needs to be increased serious awareness of the threat of the periodical Merapi eruption disaster to reduce the loss of lives.

The women living in the Merapi Slope are those who are most vulnerable to the impacts of eruption. Such condition demands them to constantly prepare themselves for the event of disasters in order to be able to save themselves and their families. Those living in the disaster-prone area of the Merapi eruption are highly vulnerable, especially as the eruption occurs regularly and they have to care for themselves, the children, and the elderly in the family. In order to reduce the vulnerability and disaster risk for those living in the Merapi Slope, there needs to be a significant effort so that they are able to face the risk and impacts of the disaster. In relation to that, this research intends to study the problems of the women living in the Merapi Slope, particularly in their vulnerabilities and disaster risk. Based on the background of the problem, the characteristics of women's vulnerabilities and their efforts in reducing the disaster risk of Merapi eruption in the South Merapi Slope can be identified.

Women have a strategic role in dealing with disaster and minimizing its risk, particularly through their improved role in mitigation. In order to improve their role in minimizing disaster risk, there needs to be improvement in the following aspects: awareness of the environment and natural threats; understanding of the vulnerability and ability to consider their own capacities; the ability to measure the risk of being a woman as an individual, a family member, and a community member; the ability to plan and act in order to reduce risks through capacity building and reducing vulnerability; and the ability to monitor, evaluate, and ensure the sustainability of risk reducing efforts to limit or prevent the post-disaster effects 
Social vulnerability in Indonesia is relatively high and can be found mostly in women living in disasterprone areas. It is imperative that the vulnerability and risks of these women in relation to the disaster be identified in order to protect and empower women from the impacts of the disaster. Women are one of the most marginalized groups in the society during the occurrence of disaster (Siagian, Ritonga, \& Purhadi, 2013):

write that three main driving factors affecting social vulnerability in Indonesia are found: 'socioeconomic status and infrastructure,' 'gender, age and population growth' and 'family structure.'. The results have shown that social vulnerability is varied significantly among districts in Indonesia. Three driving factors affecting social vulnerability have been identified, i.e., 'socioeconomic status and infrastructure', 'gender, age and population growth' and 'family structure.

The impacts of disaster in one area are different from those in another depending on the level of preparedness, endurance and capacity for recovery. When there is no proper disaster management, it is possible that vulnerability occurs longer after a disaster strike.

Disaster destroys the hopes and future of many as it often results in the loss of lives, material loss and damage, the loss of source of income and the ruin of social system. In the event of natural disaster, the following impacts can be varied, e.g. social vulnerability, decreased prosperity, threat to main occupation and food security, lack of self and social protection and security, declining health, material loss, as well as distortion on social structure and organizational network (Cardona, 2011).

The planning and implementation of a policy should not only address short-term problems. Early studies on disaster and its impacts, evacuation stage, and sustainable recovery are as crucial as the community's readiness in dealing with disaster. Policy planning on disaster requires a solid integration among various contributing factors, including natural, environmental, infrastructural, social, political, cultural, and economic aspects. Community empowerment is highly imperative in dealing with disaster, including in social, economic, cultural empowerment, as well as the assurance of health, and the availability of food, clothes, and shelter. It is also important to take into account the explicit disaster mitigation management in order to protect the community and life assets as the foundation to continue life after the disaster strike.

An analytical framework was developed to evaluate the various dimensions of decentralized disaster risk reduction, which necessitated the use of a desk study, semi-structured interviews and a gap analysis. Key barriers to implementation in Indonesia included: capacity gaps at lower institutional levels, low compliance with legislation, disconnected policies, issues in communication and coordination and inadequate resourcing. However, any of these barriers are not unique to disaster risk reduction, and similar barriers have been observed for decentralization in other developing countries in other public sectors (Grady, Anthony, Gersonius, \& Berry, 2016):

When a disaster strikes, the top priority is to save lives. The protection of security, health, facilities, and infrastructure to sustain life, such as clean water and food security, should be the first priority after 
rescue. Women are the most vulnerable members of the society when a disaster strike. Women's vulnerability should be taken into account and given proper attention as they are the true backbone of the community in preventing the negative impacts of disaster risk.

The efforts to manage disasters are constantly studied both through scientific research and official regulation in order to minimize their impacts. It is increasingly realized that the role of women has become incredibly important in reducing disaster risks and at the same time strengthen their endurance when disaster strikes. The planning and implementation of a policy should not only address short-term problems. Policy planning on disaster requires a solid integration of various contributing factors, including natural, environmental, infrastructural, social, political, cultural, and economic aspects. In dealing with disaster, women empowerment is highly essential, particularly in the social, economic, and cultural empowerment. The role of women in mitigation should be bigger as they are able to reduce vulnerabilities caused by disasters such as famine, limitation of access, loss of home, and declining health which can result in further conflict in the future.

\section{Study Area}

The research area in South Merapi slope area, Sleman Regency, Special Region of Yogyakarta, Indonesia.

\section{Methodology}

This research is a survey research using descriptive quantitative method. Data is collected through interviews. Data sources of this study are population was married women residing in South Merapi slope area. The research variables included the women's vulnerability and disaster risk on the Merapi volcanic eruption, which they regularly faced. There were primary and secondary data in this research. The former represented the characteristics of women demography, their vulnerability, as well as the disaster risk of Merapi eruption, while the latter comprised any information and data obtained from relevant studies and institutions. The primary data was grouped into qualitative and quantitative data. For this reason, the data collection was conducted in two stages, i.e., primary data collection to obtain qualitative data, and another to obtain quantitative data. Nevertheless, it must be pointed out that the classification is not exclusive (Babbie, 2007). The analysis of the research data was grouped into quantitative and qualitative data analyses. The descriptive quantitative analysis was applied on the primary and secondary data related to the women demography, including age, occupation, education level, land occupation, income, and the use of transportation modes, communication, as well as health facilities. Frequency tables were used to explain the pattern and distribution of characteristics of the variables. The relative frequency value was obtained by dividing each class's frequency with the total observation times 100 . The descriptive quantitative analysis was based on the association in learning the pattern and distribution of a phenomenon, which was supported by the result of field observation. The qualitative data were analyzed based on Miles \& Huberman (1993) following the steps of data reduction, presentation, and verification. 


\section{Results}

\section{Characteristics of Women's Vulnerability and Disaster Risk}

The village of Srunen is located in the southern part of Merapi slope. The northern part of the village shares a border with the Kalitengah Kidul village; the southern part is bordered by Singlair village, Glagahardjo village, Cangkringan District; the eastern part borders with Klaten; and the western part borders with Kepuhardjo village and District of Cangkringan. The distance from Kalitengah Lor to both the government center in Glagaharjo village and that in Kecamatan Cangkringan is about $4 \mathrm{~km}$, while the distance to Sleman Regency and Special Region of Yogyakarta regional government is $23 \mathrm{~km}$ and $32 \mathrm{~km}$, respectively. The main occupation of Srunen villagers is farmers. Almost all households have livestock, usually cows, at least one cow. The role of women in the farming activities includes looking for greens to feed the livestock, caring for the livestock, as well as taking the produce.

In the economic activity, women's role is no different from that of men's in the village. The unfortunate state of the village's accessibility is one of the factors for the villager's low household income. In addition to farming, the main occupation of the villagers is to manage and work the dry land around the village. Women's vulnerability to disaster risk can be examined from the characteristics of their financial, political, house construction and motivational vulnerabilities.

Financial vulnerability indicators include bank saving, jewelries, as well as moveable and immovable properties. 
Table 1

Financial Vulnerability

\begin{tabular}{|c|c|c|c|c|c|}
\hline \multirow[t]{2}{*}{ No. } & \multirow[t]{2}{*}{ Financial Vulnerability } & \multicolumn{2}{|c|}{ Present } & \multicolumn{2}{|c|}{ Absent } \\
\hline & & $f$ & $\%$ & $f$ & $\%$ \\
\hline 1 & Saving account & 4 & 11.75 & 30 & 88.25 \\
\hline 2 & Jewelry & 17 & 50.00 & 17 & 50.00 \\
\hline \multirow[t]{5}{*}{3} & Moveable Properties & & & & \\
\hline & Motorcycle & 34 & 100.00 & 0 & 100.00 \\
\hline & Car & 2 & 5.88 & 32 & 94.12 \\
\hline & Livestock & 34 & 100.00 & 0 & 0 \\
\hline & Others & 3 & 8.83 & 31 & 91.17 \\
\hline \multirow[t]{4}{*}{4} & Immovable Properties & & & & \\
\hline & Business Establishment & 3 & 8.83 & 31 & 91.17 \\
\hline & House & 34 & 100 & 0 & 0 \\
\hline & Land & 34 & 100 & 0 & 0 \\
\hline 5 & Insurance & 2 & 5.88 & 32 & 94.2 \\
\hline
\end{tabular}

Women's financial vulnerability could not really be seen in the village, as seen by the ownership of both movable and immovable properties such as motorcycles, livestock, and land as financial power. On the other hand, only $11.75 \%$ of women owned a bank saving account.

Social vulnerability indicators include having family members of toddlers, elderly, and more female members than men. Others also include having a family member in a safe and easily accessible area, having a good understanding of disaster, having family members with a good understanding of disaster, as well as having an active part in a disaster-responsive social organization in the community. 
Table 2

Social Vulnerability

\begin{tabular}{|c|c|c|c|c|c|}
\hline \multirow[t]{2}{*}{ No. } & \multirow[t]{2}{*}{ Social Vulnerability } & \multicolumn{2}{|c|}{ Present } & \multicolumn{2}{|c|}{ Absent } \\
\hline & & f & $\%$ & f & $\%$ \\
\hline \multirow[t]{5}{*}{1} & Having family member of & & & & \\
\hline & Toddlers & 11 & 32.35 & 23 & 67.65 \\
\hline & Elderly & 19 & 55.88 & 15 & 44.12 \\
\hline & Disabled & 1 & 2.94 & 33 & 96.06 \\
\hline & More women than men & 27 & 79.41 & 7 & 20.59 \\
\hline 2 & Having a family member in a safe and easily accessible area & 9 & 26.47 & 25 & 73.52 \\
\hline 3 & Having a good understanding of disaster & 19 & 55.88 & 15 & 44.12 \\
\hline 4 & Having family members with a good understanding of disaster & 23 & 67.64 & 11 & 32.36 \\
\hline 5 & $\begin{array}{l}\text { Having an active disaster-responsive social organization in the } \\
\text { community }\end{array}$ & 14 & 41.18 & 20 & 58.82 \\
\hline
\end{tabular}

Women's social vulnerability is shown by $55.8 \%$ of them having at least one elderly person in the family, while $79.41 \%$ said that there were more women than men in the family. Only $26.47 \%$ had family members living in safe and accessible areas, while the other $73.52 \%$ did not. There is a balanced number of women who have a good understanding of disaster $55.8 \%$. As many as $67.64 \%$ of the women had family members with good understanding of disaster, and $58.82 \%$ had an active disaster-responsive social organization.

The indicators of environmental vulnerability include being prone to landslide, volcanic mudflow threat, volcanic rain mudflow threat, land damage, place of business damage, as well as infrastructure damage all of which are suffered by the women living in the area under study. 
Table 3

Environmental Vulnerability

\begin{tabular}{|llllll|}
\hline \multirow{2}{*}{ No. } & Environmental Vulnerability & \multicolumn{2}{l}{ Present } & \multicolumn{2}{l}{ Absent } \\
\cline { 3 - 6 } & & $\mathbf{f}$ & $\%$ & $\mathbf{f}$ & $\%$ \\
\hline 1. & Being prone to landslide & 21 & 61.76 & 13 & 38.23 \\
\hline 2. & Volcanic mudflow threat & 25 & 73.52 & 9 & 26.48 \\
\hline 3 & Volcanic rain mudflow threat & 23 & 67.64 & 11 & 32.36 \\
\hline 4. & Land damage & 19 & 55.88 & 15 & 44.11 \\
\hline 5. & Place of business damage & 27 & 79.41 & 7 & 20.59 \\
\hline 6. & Infrastructure damage & 26 & 76.47 & 8 & 23.52 \\
\hline
\end{tabular}

Most women living in the area under study must deal with the landslide threat, volcanic mudflow, volcanic rain mudflow, land and place of business damage, as well as infrastructure damage. The biggest vulnerability in relation to environment is place of business damage with $79.47 \%$ and land damage with $55.88 \%$.

The indicators of organizational vulnerability include proactive disaster mitigation organization, being active in disaster mitigation forum/organization, understanding of the procedure in reducing risk, regular and sustainable guidance on disaster, and regular and sustainable counseling in the community living in the affected area.

Table 4

Organizational Vulnerability

\begin{tabular}{|llllll|}
\hline No. & Organizational Vulnerability & \multicolumn{2}{c}{ Present } & \multicolumn{2}{c|}{ Absent } \\
\cline { 3 - 6 } & & $\mathbf{f}$ & $\%$ & $\mathbf{f}$ & $\%$ \\
\hline 1. & Proactive disaster mitigation organization & 32 & 94.12 & 2 & 5.88 \\
\hline 2. & Being active in disaster mitigation forum/organization & 4 & 11.75 & 30 & 88.25 \\
\hline 3 & $\quad$ Understanding of the procedure in reducing risk & 12 & 35.30 & 22 & 64.70 \\
\hline 4. & Regular and sustainable guidance on disaster & 11 & 32.36 & 23 & 67.64 \\
\hline 5. & $\begin{array}{l}\text { Regular and sustainable counseling in the community living in } \\
\text { the affected area }\end{array}$ & 17 & 50.00 & 17 & 50.00 \\
\hline
\end{tabular}

There is $94.12 \%$ proactive disaster mitigation, although $88.25 \%$ of the women showed a lack of participation in the forum/organization. Some $64.70 \%$ of the women showed their lack of understanding 
of the risk-reduction procedure, and $67.64 \%$ revealed that there was no regular and sustainable guidance on disaster.

The indicators of education vulnerability include the limited access to information, knowledge, and education infrastructure.

Table 5

Education Vulnerability

\begin{tabular}{|llllll|}
\hline \multirow{2}{*}{ No. } & Education Vulnerability & \multicolumn{2}{l}{ Present } & \multicolumn{2}{l|}{ Absent } \\
\cline { 3 - 6 } & & $\mathbf{f}$ & $\%$ & $\mathbf{f}$ & $\%$ \\
\hline 1. & Limited Access to Information & 2 & 5.89 & 32 & 94.11 \\
\hline 2. & Limited Access to Knowledge & 7 & 20.59 & 27 & 79.41 \\
\hline 3 & Limited Access to Education Infrastructure & 7 & 20.59 & 27 & 79.41 \\
\hline
\end{tabular}

Women living in the area under study did not experience education vulnerability involving vulnerability in gaining access to information, knowledge, and education infrastructure. Education vulnerability was not present as there was no difficulty in gaining access to information $(94.11 \%)$, while $79.41 \%$ of women did not experience any difficulty in gaining access to knowledge and education infrastructure.

The indicators of political vulnerability include the lack of assistance, the lack of counseling, the lack of government aid, lack of option to live safely, and being exploited in the National and Legislative Elections.

Table 6

Political Vulnerability

\begin{tabular}{|llllll|}
\hline \multirow{2}{*}{ No. } & Political Vulnerability & \multicolumn{2}{l}{ Present } & \multicolumn{2}{l|}{ Absent } \\
\cline { 3 - 6 } & & $\mathbf{f}$ & $\%$ & $\mathbf{f}$ & $\%$ \\
\hline 1. & Lack of assistance & 7 & 20,59 & 27 & 79,41 \\
\hline 2. & Lack of counseling & 5 & 14,71 & 29 & 85,29 \\
\hline 3 & Lack of government aid & 0 & 0 & 34 & 100,00 \\
\hline 4. & Lack of option to live safely & 23 & 67,65 & 11 & 32,35 \\
\hline 5. & Being exploited in the National and Legislative Elections & 29 & 85,30 & 5 & 14,70 \\
\hline
\end{tabular}

Some of the indicators of political vulnerability including the lack of assistance, the lack of government aid, and the lack of option to live safely were not dominantly present among the women living in the area under study. Almost all of them received disaster-related government aid. 
The indicators of house construction vulnerability include housing complex close to the river basin area (RBA) with direct path to Merapi, the distance of the house to the Merapi summit, place of business close to the RBA with a direct path to Merapi, the distance of the place of business to Merapi summit, the availability of transportation mode in the event of disaster, the accessibility to the evacuation place, and the availability of security facilities.

Table 7

House Construction Vulnerability

\begin{tabular}{|c|c|c|c|c|c|}
\hline \multirow[t]{2}{*}{ No. } & \multirow[t]{2}{*}{ House Construction Vulnerability } & \multicolumn{2}{|c|}{ Yes } & \multicolumn{2}{|l|}{ No } \\
\hline & & f & $\%$ & f & $\%$ \\
\hline 1 & $\begin{array}{l}\text { Housing complex close to RBA with }<100 \text { m direct path to } \\
\text { Merapi }\end{array}$ & 18 & 52.94 & 16 & 47.06 \\
\hline 2 & Housing complex with $<5 \mathrm{~km}$ distance to Merapi summit & 0 & 0 & 34 & 100.00 \\
\hline 3 & $\begin{array}{l}\text { Place of business close to RBA with }<100 \mathrm{~m} \text { direct path to } \\
\text { Merapi }\end{array}$ & 2 & 5.89 & 32 & 94.11 \\
\hline 4 & Place of business with $<5 \mathrm{~km}$ distance to Merapi summit & 0 & 0 & 34 & 100.00 \\
\hline 5 & $\begin{array}{l}\text { The availability of transportation mode in the event of } \\
\text { disaster }\end{array}$ & 34 & 100.00 & 0 & 0 \\
\hline 6 & The accessibility to the evacuation place & 29 & 85.29 & 5 & 14.71 \\
\hline 7 & The availability of security facilities & 18 & 52.94 & 16 & 47.06 \\
\hline
\end{tabular}

Some $52.94 \%$ of housing complex in the river basin of Mt Merapi were less than $100 \mathrm{~m}$ away from the riverside, while $100 \%$ of the women did not live less than $5 \mathrm{~km}$ away from the summit. Similarly, $100 \%$ of the women also did not find the lack of place of business near the volcano summit (less than $5 \mathrm{~km}$ away). There was a balance in the availability of transportation in the event of disaster, easy access to the evacuation place, and availability of security facilities for women living in the area under study. Many residents live on the slopes of 130 active volcanoes in Indonesia for thousands of years (Lavigne et al., 2008). Java Island is the center of population concentration and has many potential volcanic disasters compared to other regions in Indonesia (Setyowati, Pramono \& Ashari, 2015). So, the population living around Merapi is increasing.

\section{Discussion}

\section{Women's Efforts in Disaster Mitigation}

There are a few disaster mitigation efforts made by the women living in the area under study in order to prepare for the frequent Merapi-related disasters, including recognizing the signs of natural disasters, characteristics of the volcano, recognizing the dangerous parts of the area, building an early warning 
system, listening to community radio for the update news on the volcano's status, recognizing signs of natural disaster, characteristics of the volcano and its threats, dangerous parts of the area, building an early warning system, listening to community radio for the update news on the volcano's status, understanding the route and available shelter with basic necessities when required, making a disaster mitigation plan, preparing basic necessities and important documents, monitoring the information by the Volcanic Observation Station, self-protection in the event of disaster by building a temporary shelter and preparing all the easy-to-reach and ready-to-bring necessities in case of evacuation.

Mrs. Walyani was able to identify the characteristics and threats of the volcano. She had lived in the village since she was a child. Her parents taught her about the characteristics of the area where they lived and how prone they were to volcanic eruption. Her parents taught their kids to be constantly aware of the volcanic presence.

She said "...only by paying attention to the signs of disaster did I pay attention... every time there is information on the Merapi volcanic activity...."

Mrs. Samini and Mrs. Wintaris began to be familiar with the dangerous parts of the area when attending counseling program from the government and relevant organizations involved in the disaster mitigation of the villagers around the Merapi slope. They were two of the women who were active in the social activities in the area under study.

Mrs. Samini and Mrs. Wintaris tried to recognize the dangerous parts of the area as they received information from the officials. They said that it was helpful to follow the government officials' guidance program on the dangerous areas.

Together with the Taruna Siaga Bencana (TAGANA) group, Mrs. Martini and Mrs. Samirah are active in the early warning system. Merapi is an active volcano that can be a threat for the surrounding village. The community plays a great role in actively providing constant information for the villagers so that they are always alert and ready.

Mrs. Martini and Mrs. Saminah said that they were taught to build an early warning system by recognizing the signs of the nature especially the sign when the eruption is about to happen.

Community radio is one of the essential means of information for the villagers in the area under study. They need to keep updated on the Merapi's volcanic activities from time to time and the radio plays a strategic role in providing reliable and accurate information on the matter, particularly when the volcano is in its dangerous state.

Mrs. Samirah and Mrs. Lasmi described that they followed the community radio to gain information on the volcanic status of Merapi including what the community had to do. The steps in dealing with the disaster were communicated through the community radio. 
The people are guided and assisted by the local government and relevant institutions in preparing a route and shelter with the necessary facilities when Merapi is in its active state. As the volcanic threats force people to leave their homes, the shelter becomes an alternative for the villagers of the area under study. According to Mrs. Lasmi and Mrs. Mariana, they preferred evacuating with their neighbors in the event of disaster to living in their relatives' houses in the safer area. This is partly because they could still leave the shelter for a while to feed their livestock in the village. Mrs. Lasmi and Mrs. Mariana explained that it was important to prepare a route and shelter ready with basic necessities in a spirit of togetherness and the women and all villagers worked together to do rescue steps by studying and preparing evacuation route.

A disaster management plan in the area under study is made by involving the community. There was increasing awareness among the community that the area they lived in was a disaster-prone area. Mrs. Wintaris and Mrs. Martini were two of the women active in the disaster management activities. They actively participated in the counseling and mitigation training held by various stakeholder institutions. The two women represented the community to involve in the disaster mitigation from the early planning management stage.

One of them said, "...I was involved in the planning of disaster management in our village....After participating in the counseling I transfered my knowledge to other women here...I hope that by involving the community from the planning stage... when the disaster strikes... we can be more prepared."

Mrs. Sukini did the disaster mitigation preparation by making sure that the basic necessities and important documents were ready to carry away in the case when they needed to take refuge or were asked to leave the village temporarily until the volcanic activities calmed down. Mrs. Sukini mentioned the mitigation efforts to prepare important documents and necessities in the refugee shelter.

She said, "...I always prepared one ready-to-go bag with basic necessities and important documents for when I have to flee...that way, I can save time and focus on leaving for the shelter ...."

The community of the Merapi slope has a good understanding of the importance of warnings and updates on the information related to Merapi's volcanic activity. One of their most trusted sources is the Volcanic Observation Station. The community's interest in the information increases when the volcanic status is upgraded. According to Mrs. Watinah, the information from the Station is reliable and therefore made as a reference or guidance for them to take the next step in rescuing their families and saving their possessions.

Mrs. Watinah explained "...the importance of monitoring the information given by the volcanic observation...especially when Merapi is active, we must keep updated on the information from the post...."

As the volcanic activities of Merapi are limited by time and stages, the people around the volcano can plan their rescue initiatives using the guide from the officials as a reference. Mrs. Laksmi usually builds a temporary shelter when Merapi's activity is still tolerable, so that other villagers do not have to flee or leave their homes. The community considers that Merapi's activities can be classified in stages, and 
therefore they need different strategies to handle them. In general, the villagers in the area under study have a temporary shelter for their family. When Merapi is in a dangerous state, only men are allowed to stay in the village. In this case, the temporary shelter works as an alternative way for self-protection.

Mrs.Laksmi explained that she protected herself and her family when disaster struck by building a temporary shelter, and the most solid building in the house was used as an alternative temporary shelter.

When Merapi is active, the surrounding villagers will be evacuated temporarily from their homes as advised by the experts and officials. They will return to their daily lives and activities when Merapi is back to normal. On the one hand, Merapi is a blessing for the villagers as it provides them with natural resources such as rocks and sands which they mine to make a living. On the other hand, they are aware that the volcano can be a threat, and prepared to flee when the time comes.

Mrs. Wintari prepared all the easy-to-reach and ready-to-carry necessities when they have to flee, as she said, "...I need to take refuge for a while as the Merapi is active..."

Mount Merapi is one of the volcanoes in Java, it is the most active and dangerous volcano in Indonesia in the past hundred years, Merapi is well-known for producing small volume pyroclastic flows from lava domes called hot clouds and its vocal activity continues to this day, so the impact of eruption is intense and deadly (Gertisser et al., 2012: 1214; Plummer, Carlson, \& Hammersley, 2016: 78; Wu, Griessbach, \& Hoffmann, 2018: 3, Muthiah, Muntasib, \& Meilani, 2018: 1; Otani et al., 2018: 79). Merapi is very dangerous. In spite of, Merapi is both a threat and a gift for the people of the area under study. One of the efforts in dealing with Merapi is to retreat when it shows any volcanic activity. How dangerous the eruption of Merapi, but the community still survive in the region. Therefore, people need to make efforts to reduce the impact caused by the eruption of Merapi. Women in Merapi have been involved in reducing the effects of eruptions. Women participation in preparedness activities in sleman district has been running even though its participation still limited. Hastuti \& Widyawati (2019) that, post-disaster women begin to pioneer economic activities such as raising livestock, managing agricultural land for immediate replanting, opening stalls and trading, and searching for sand and stones for additional income.

\section{Conclusions}

Women in the village of Srunen show financial vulnerability in terms of lack of saving in the bank, as well as lack of protection on the place of business, land, and residence. The social vulnerability of these women is shown by the number of most women and elderly people who are in need of protection from natural disasters. Organizational vulnerability caused by the lack of relevant organization that takes care of women is another problem that women are faced in disaster mitigation. Most social organizations involve more men than women. On the other hand, the environmental vulnerability experienced by women includes the threats of natural disaster such as landslide and volcanic mudflow, especially for those living in the river basin area with a direct path to Merapi. 
The mitigation efforts made by the women include the ability to recognize the signs of natural disasters, characteristics of the volcano and its threats, dangerous parts of the area, building an early warning system, listening to community radio for the update news on the volcano's status, understanding the route and available shelters with basic necessities when required, making a disaster mitigation plan, preparing basic necessities and important documents, monitoring the information by the Volcanic Observation Station, self-protection in the event of disaster by building a temporary shelter, and preparing all the easy-to-reach and ready-to-bring necessities in case of evacuation.

\section{Declarations}

Acknowledgements

Thankyou to all the Donoharjo Village and Candibinangun Village people who have taken the time to do the research and assistants who assist with data collection so that this asticle can be finished.

Author contributions

All authors were involved in the preparation of this article. $\mathrm{H}$ makes concepts, methods, data collection, analysis and makes conclusions. EW takes data and compiles maps. SRG and PW analyze the data.

\section{Funding}

This research was fully funded by private authors.

Availability of data and materials

The datasets used and/or analysed during the current study are available from the corresponding author on reasonable request.

Competing interests

The authors declare that they have no competing interests

\section{References}

Babbie. The Basics of Social Research, Wadsworth. 2007.

Badan Pusat Statistik (BPS). Biro Pusat Statistik.; BPS: Jakarta, Indonesia. 2015.

Grady, A., B. Gersonius, and A. Makarigakis. 2016. Taking stock of decentralized disaster risk reduction in Indonesia. Natural Hazards and Earth Systems Sciences 2016: 16, 2145-2157.

Cardona, O. D. 2011. Disaster Risk and Vulnerability: Concepts and Measurement of Human and Environmental Insecurity. In Hexagon Series on Human and Environmental Security and Peace; Brauch, H.G., Eds.; Springer-Verlag Berlin: Heidelberg, Germany, (2011).

Cho, S. E., S. Won, and S. Kim. 2016. Living in Harmony with Disaster: Exploring Volcanic Hazard Vulnerability in Indonesia. Sustainability, (2016), 8, 848. DOI:10.3390/su8090848 2. 
Gertisser, R., S. J. Charbonnier, J. Keller, and X. Quidelleur. 2012. The geological evolution of Merapi vulcano, Central Java, Indonesia. Bull Volcanol, Vol. 74. Hal. 1213-1233.

Hastuti, and M. Widyawati. 2019. Women's Role In Post-Disaster Recovery in South Merapi Slopes. IOP Conf. Series: Earth and Environmental Science 271 (2019) 012001. doi:10.1088/1755-

1315/271/1/012001.

Lavigne, F., B. D. Coster, N. Juvin, F. Flohic, J. C. Gaillard, P. Texier, J. Morin, and J. Sartohadi. 2008.

People's behaviour in the face of volcanic hazards: Perspectives from Javanese communities, Indonesia. Journal of Volcanology and Geothermal Research, Vol. 172, Hal. 273-287.

Miles, M. B., and M. A. Huberman. 1994. Qualitative data analysis: an expanded sourcebook, 2nd edn. Thousand Oaks, CA: Sage.1994.

Miles, R., and L. Panton. 2006. The Influence Of The Perceived Quality Of Community Environment On Low Income Women's Efforts To Walk More. J. Community Health., 2006, 31. DOI: 10.1007/s10900-0069021-9.

Muthiah, J., E. K. S. H. Muntasib, and R. Meilani. 2018. Tourism hazard potentials in mount merapi: how to deal with the risk. IOP Conf. Series: Earth and Environmental Science 149, Hal. 1-11.

doi:10.1088/1755 - 1315/149/1/012020.

Otani, K., D. Legono, S. Darsono, and Suharyanto. 2018. Effects of disaster management programs on individuals' preparedness in mount merapi. Journal of the Civil Engineering Forum, Vol. 4, No. 1, January, Hal. 79-90.

Plummer, C. C., D. H. Carlson, and L. Hammersley. 2016. Physical geology. New York: Mc Graw-Hill Education.

Setyowati, S., H. Pramono, and A. Ashari. 2015. Kecerdasan tradisional dalam mitigasi bencana erupsi pada masyarakat lereng baratdaya gunungapi merapi. Jurnal ilmu-ilmu sosial (Socia), September, Vol.12, No. 2, Hal. 100-110.

Siagian, T. H., and H. Purhadi.; Suhartono.; Ritonga. 2013. Social vulnerability to natural hazards in Indonesia: driving factors and policy implications. Springer Science Business Media: Dordrecht, Netherlands, 2013.

Tuswadi Takehiro Hayashi dan Tuswadi. 2014. Disaster Prevention Education in Merapi Volcano Area Primary Schools: Focusing on Students' Perception and Teachers' Performance. Procedia Environmental Sciences Volume 20, 2014, Pages 668-677.

UNDP. 2007. A Global Review: UNDP Support to Institutional and Legislative Systems for Disaster Risk Management. UNDP: New York, USA, 2007; pp. 4-10.

Wu, X., S. Griessbach, and L. Hoffmann. 2018. Long-range transport of volcanic aerosol from the 2010 merapi tropical eruption to antarctica. Journal Atmospheric Chemistry and Physics.

https://doi.org/10.5194/acp-2018-332.

\section{Figures}




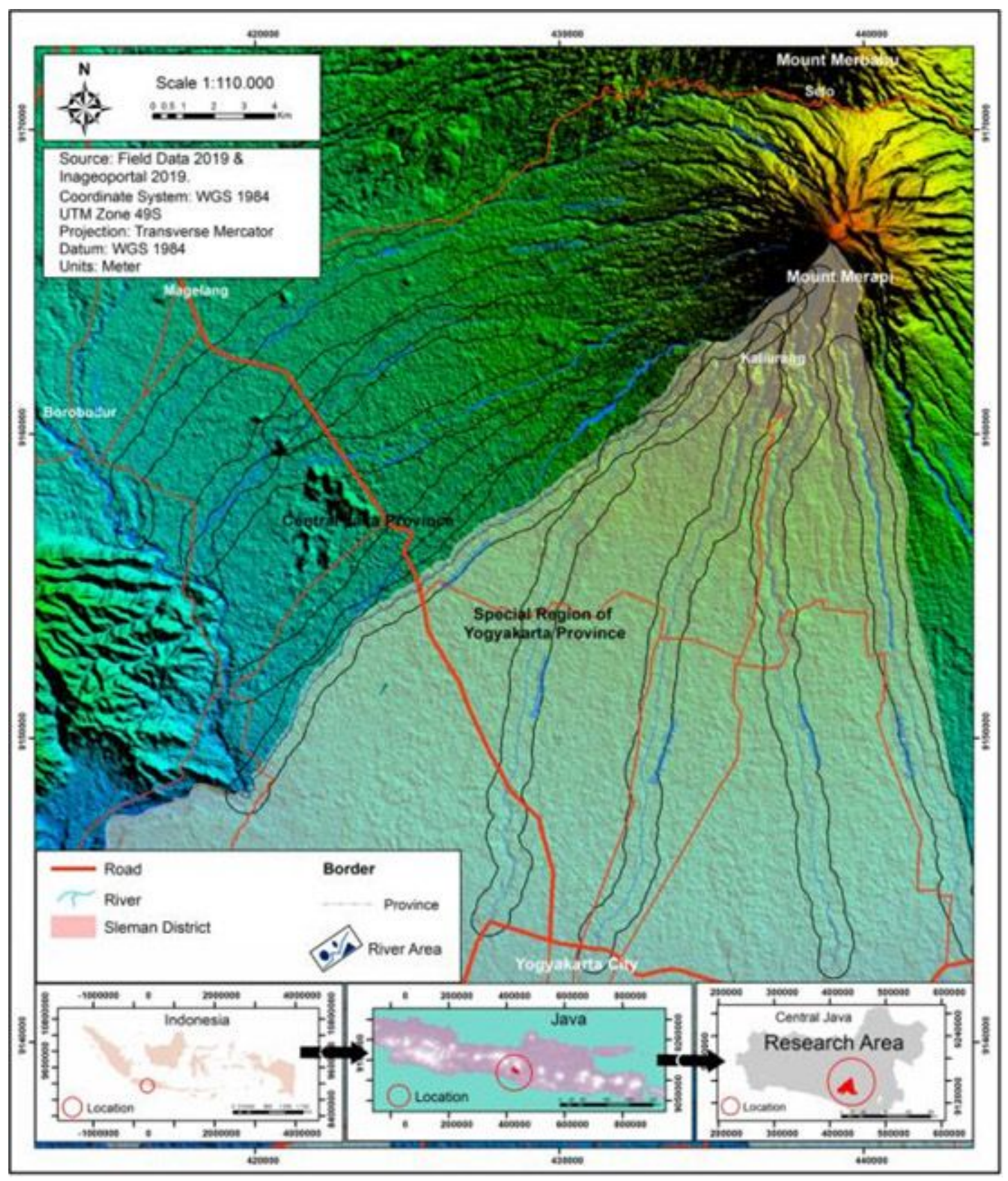

Figure 1

Research Area 


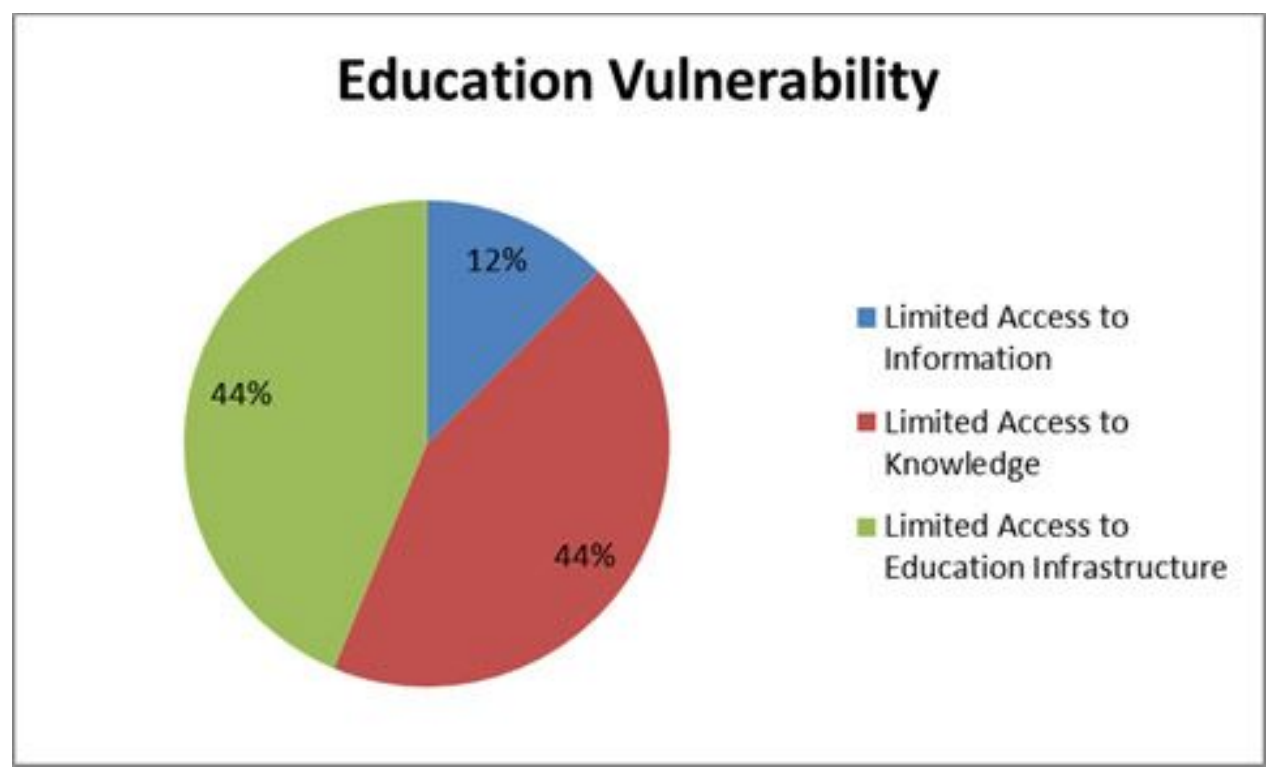

Figure 2

Education Vulnerability 